\title{
TYPOLOGY OF THE TRANSFORMATIONS OCCURRED IN THE PERI-URBAN SPACE OF HUERTA DE VALENCIA. EVIDENCE FROM NORTH ARCH OF VALENCIA (SPAIN)
}

\author{
R. TEMES \& A. MOYA \\ Department of Urban Design and Regional Planning, Polytechnic University of Valencia, Spain
}

\begin{abstract}
This paper present the outputs obtained from the measurement and classification of the different types of changes happened in the last 70 years on the Northern area of expansion of the city of Valencia. The city has progressively been covering, with different rhythms and intensities, the space of La Huerta. We can identify between 1944 and 2014 a group of transformations that occur repetitively, building a change pattern identified as common on the city's expansion evolution. The methodology is based on the analysis and measurement of changes occurred on land structure, land use, buildings occupation and on the traditional structure of non-urban roads. The key sources to measure such changes have been the use of the Cadastre of 1929-1944; 1972; and 1989; the orthophoto collections from the Valencian Regional Library and the evolution of SIOSE mapping. The most outstanding results refer to the surprising resilience of some elements from the structure of La Huerta de Valencia and the discovery and identification of the main transformations patterns that could be generalized to the rest of La Huerta de Valencia.
\end{abstract}

Keywords: GIS, huerta de valencia, resilience, urban transformations, valencian community.

\section{INTRODUCTION}

The word "Huerta" is a concept of universal scope used in various parts of the world of Hispanic influence, in Europe and America, to designate a peculiar irrigated landscape based on specific criteria of social organization and distribution of water, based on collective rights and its apportionment among irrigators. Although all the changes taking place in the history of la Huerta de Valencia have marked their process of organization and development, there are three important historical moments that have played an important role in the formation of the Huerta [1]:

- The Muslim period that contributed to the construction of the infrastructure that have allowed to the development of agriculture in the area, until today. As noted by the Territorial Action Plan for the Protection of la Huerta de Valencia (PATPH), la Huerta and its specific irrigated landscape has its historical concretion in the hydraulic spaces genesis created by the medieval Muslim society, which were adopted throughout the Mediterranean Arab area that expanded westward to reach the Maghreb and al-Andalus. This is precisely one of its most characteristic traits: la Huerta is a specific, definable and recognizable historical concept which corresponds to a model of irrigation that was created in a particular historical period, the Medieval Age.

- The feudal period and distribution of land. As Guinot indicates[1], with the 1,238 feudal conquest, the division of la Huerta conducted by king Jaime I clearly created a new land-

This paper is part of the Proceedings of the $3^{\text {rd }}$ International Conference on Environmental and Economic Impact on Sustainable Development (Environmental Impact 2016)

www.witconferences.com 
based feudal hierarchy which involved the creation of territorial feudal estates, with large farms and small peasant holdings as well as a generalization of the small family farm. All this culminated in a major land subdivision of the territory as large estates were given to direct growers in smaller plots. However, the Feudal distribution of the XIII century does not imply a radical replacement of the Andalusian landscape. They had to respect the ditches and main roads as backbones of the landscape and remained mostly in the periphery of the city's original structure (where higher density plots exist). Therefore we can say, relying on the findings of Guinot that this distribution or redistribution of land has remained to this day by setting the morphologically character of the Huerta of Valencia.

- The contemporary age with the strong changes occurred in the agricultural market and its impact on farmers and the loss of land for agriculture. As reflected in the PATPH, analysis of changes in land use revealed that in 1950,10\% of the historical Huerta had disappeared and in 2006 this trend had intensified dramatically until the disappearance level reached $30 \%$.

Generally, the Mediterranean historical Huerta is known for their intimate connection to the cities. They are never simple irrigated agricultural areas. No wonder, therefore, that the history of La Huerta is inseparable from the history of the city of Valencia and its regional environment, now called metropolitan area. The reality is that Valencia has grown historically over La Huerta, but at a very slow pace and without the close link (operating, financial,
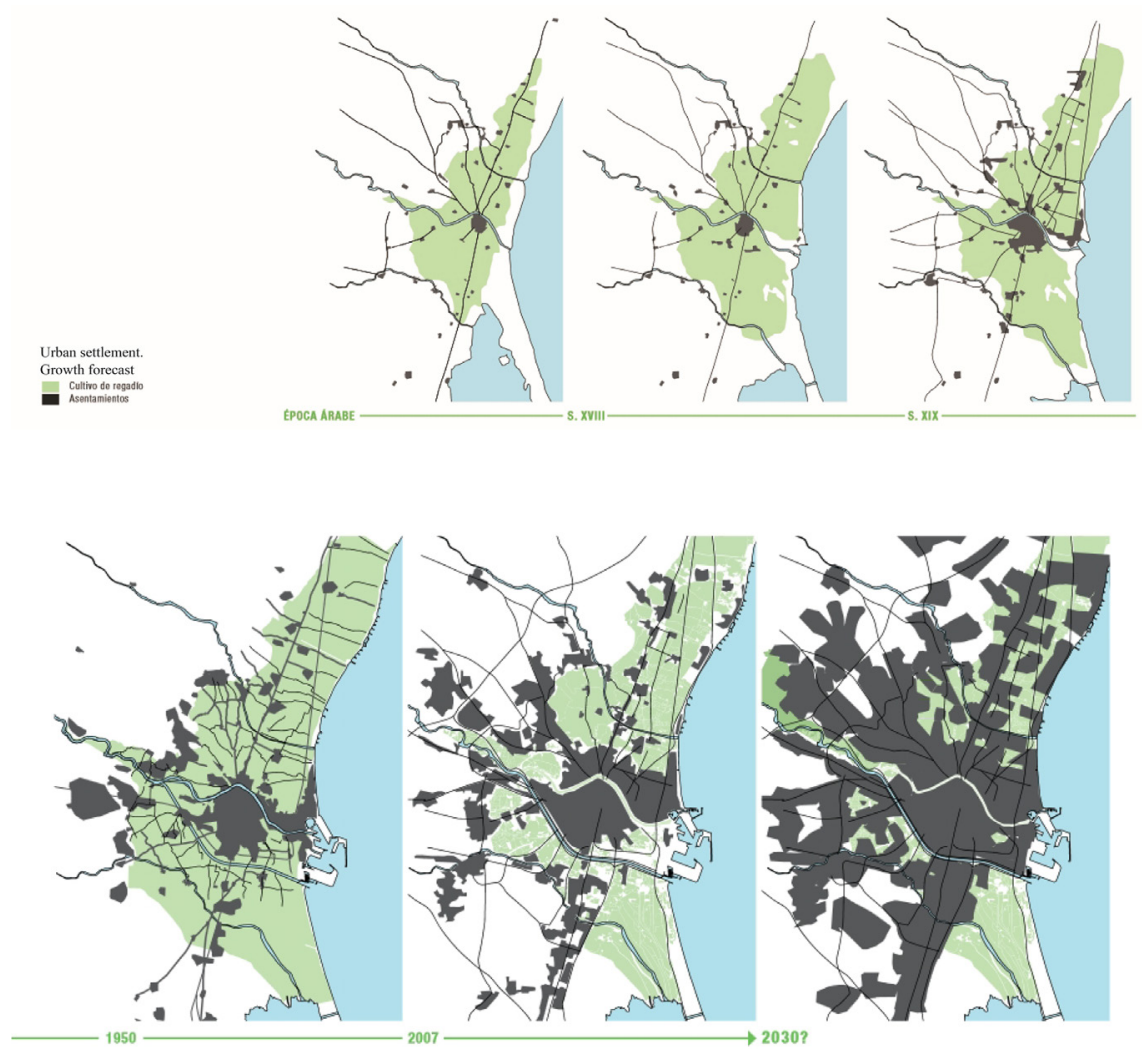

Figure 1: Evolution of artificial cover of land in Valencia. 
employment or provision of goods and services) between the city and the agricultural environment weakened. The balance began to collapse in the second half of the nineteenth century, when the city becomes a stage and, at the same time, a prominent actor in the process of industrialization that would completely change the social and economic foundations of our society, Fig. 1.

\subsection{General objectives and structure of the work}

In this work, according to an earlier research [2], it is intended to make an assessment and analysis of the transformations from 1944 to 2014 of a part of this historical Huerta of the municipality of Valencia. In particular, we will analyse the evolution in the last 70 years of the area we have named North Arch of Valencia, which is integrated in between the irrigation systems of the main ditches of Mestalla and Rascanya. For the analysis in this paper, we have defined the scope of that area of La Huerta from the districts of Campanar, Benicalap, Rascanya, Benimaclet and Algirós whose area covers 1,236 hectares. This area, due to their proximity to the northern growing edge of the city of Valencia, has suffered in the last 70 years major attacks being concentrated the largest consumption in road and different occupations. Thus, the increased consumption of land for road use occurs from 1989 to 2004 (expropriation of land for the construction of the north ring road) and higher occupancy by building occurs between 1944 and 1972, where, thanks to the General Plan of Valencia of 1947 and the General Plan of 1966, the occupation of this space is definitively decided. Still, as we concluded in previous works [2], time has demonstrated the capacity of resiliency of this space that invites to believe on its preservation despite the abuses that has had to face.

\subsection{Method of cartographic coordination}

The methodology used to do this study has been based on a comparative analysis of cartographies managed by a Geographical Information System (GIS) and already used on other studies and reports done by the authors [3]. It has also been used as a reference, not so much in its methodology but in its goal of morphological analysis, the work done previously by Guinot [4]. The primary sources for the reconstruction of the agriculture divisions of the land during the periods 1944, 1972, 1989, 2004 and 2014 have been the historical cartography base of the Cadaster. The Cadaster source has been the only one that, systematically and during the last 70 years, has done a precise and accurate description of each one of the urban and rural pots of the city. This information is, therefore, one of the most complete and trusty sources of information when facing a systematic analysis of a wide area. But, to be able to do this restitution, the collection and digitalization of the cadaster collections used was first needed. These are divided into four groups, depending on a spatial reconstruction and two different regulation situations on paper and the last series digitally collected.

Despite the quality with which the Cadaster Service has been reconstructing its plot maps along its lifetime, it is inevitable that after trying to overlay the information from different periods of time, some little deformations occur due to the accumulation of different type of errors. The immediate strategy of establishing a comparison of a same section of an area on different periods of time usually faces important problems that reduce the quality of the final results. To solve it, we have followed a specific strategy overcoming two of the main problems of the cartography. 


\subsubsection{The vertical and inverse coordination and the cartography deformation}

As we have already commented, the cartographic work of different periods of time usually brings different levels of quality that difficult the comparison of the maps. These distortions can hardly be solve by an automatize process. By doing so we are in risk of eliminating façades linings, building peculiarities or widening of streets that show variations during the study period. This is the reason of the costly and delicately process that must be done for the reconstruction of a coordinated cartography, usually accompany with a continuous consultation of complementary information to be able to understand the real situation. This process of identification is not absent of errors that must be taken into consideration to evaluate the level of exactitude of the base of the study for the analysis.

On the other hand, to be able to do a correct comparison of the different periods, we have done, on the first place, a chronological inverse reconstruction of the mapping to guarantee the correct coordination of the cartography. This means starting from the 2014 cartography and going back to the one done in 1944. We had the digital reconstruction of the plotting of Valencia of 2014 facilitated by the Web Assistance of the Spanish Cadaster [5]. With this vectorised plotting, and previous geo-position and digitalization of 1989, 1972, and 1944 cartographies, each period was vectorised. To do so, a process of, as we call, cartography coordination [6] was done which consist on a verification of relations between the cartographies of different periods, taking as support points the existing constructions or invariable points that assure the comparison of the period sequence studied. The coordination of the cartographies is not a simple process of drawing with a more or less precision of the different maps regarding different periods of a same territory, as can be understood. It is a vertical reconstruction of a cartography series that searches for buildings appearing on the different periods of time of the studied sequence.

Once the restitution has been finished, we added in the mapping the heights of each of the constructions, allowing a calculation of the total available construction area for each one of the periods. Due to the lack of information regarding qualitative data, we have used the geometrical data of the elements to obtain the areas and the available construction area. Three different types of areas have been classified: roads and facilities infrastructure, buildings and plots. The first two are what we called anthropic lands and the rest of the surfaces have been classified as portions: farm land or farming plots (one the constructions, roads and primary transportation network have been eliminated). But we are aware that the agricultural land is a creation of a human transformation, and therefore anthropic. Thus we have preferred to keep a differentiation between the agricultural land and the rest.

\section{RESEARCH DEVELOPMENT}

The area of study has been limited so it covers which, administratively is inside the city of Valencia, the districts of Campanar, Benicalap, Rascanya, Benimaclet and Algirós, where there is information about the 70 years analysis. The total area is about 1,200 ha., which represent comparably around eight times the Valencia's downtown area. The spatial coordination restitution of all the elements of the maps allows a time comparison of the cartographies, detecting the changes and transformations. The coincidence of the vertexes permits topological calculations of intersection and cutting, obtaining new geometries that limit the three types of land previously quoted.

For each one of the periods studied, a first calculation has been made regarding the surface occupied by connection and facilities infrastructures. The results are shown in Table 1.

The same procedure has been used to calculate the constructed areas, doing the subtraction of plots by using as base layer the restitution of the buildings. On the reconstruction process 
Table 1: Road network.

\begin{tabular}{ccc}
\hline Year & Surface (Ha.) & $\%$ \\
\hline 1944 & 96.27 & 7.78 \\
1972 & 162.26 & 13.12 \\
1989 & 229.44 & 18.55 \\
2004 & 328.67 & 26.58 \\
2014 & 402.01 & 32.51 \\
\hline
\end{tabular}

Table 2: Edification and potential development.

\begin{tabular}{ccc}
\hline Year & Edification (Ha.) & \% \\
\hline 1944 & 52.68 & 4.26 \\
1972 & 124.02 & 10.03 \\
1989 & 156.82 & 12.68 \\
2004 & 213.66 & 17.28 \\
2014 & 242.08 & 19.58 \\
\hline
\end{tabular}

Table 3: Portions.

\begin{tabular}{ccc}
\hline Year & Portions (Ha.) & \% \\
\hline 1944 & 1101.03 & 89.03 \\
1972 & 966.10 & 78.12 \\
1989 & 861.85 & 69.69 \\
2004 & 695.60 & 56.25 \\
2014 & 592.50 & 47.91 \\
\hline
\end{tabular}

the building' heights have been consulted which, including the surface area, allow us to calculate the final available construction area for each period. The result is shown in Table 2.

Finally, we calculate the existing agriculture plotting on each of the periods, as a result of subtracting the area occupied by constructions from the agricultural surface. This land is equal to the traditional production area of Valencia's Huerta on the North Arch of Valencia area. The results can be seen in Table 3 .

We can see how on each period of time a remarkable increase of land area dedicated to roadways and connection infrastructure as well as to facilities have been occurring. In this case, the average rate of creation of land for road infrastructure has been quite homogeneous (around 5.5\%) during the intervals of study, being somewhat higher (5.9\%) in the range from 2004 to 2014 due primarily the consolidation of the northern bypass, the largest infrastructure in the area together with the urbanization of the surrounding soils with the corresponding openings of new roads. We can also see the increase of building use in the area. While the pace of land transformation has been slower than that of road use $(3.5 \%)$ the most important increased land occupation occurs between 1944 and 1972 with the transformation of more than 70 ha. of land primarily for residential use (Table 4). In the next graphics, we can see the evolution of land uses. 


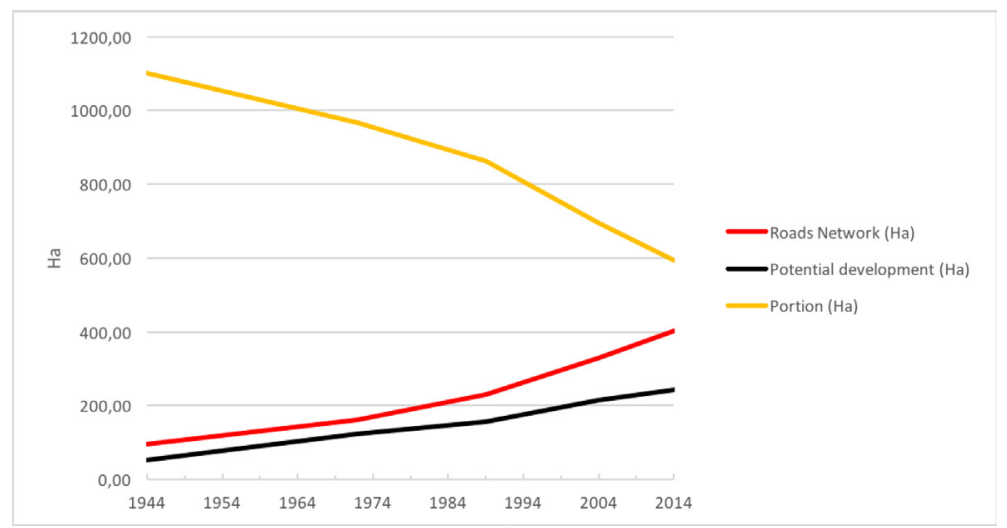

Figure 2: Land use graphic.

Table 4: Land Use Changes (sq. M.)

\begin{tabular}{lccc}
\hline Period & Portions & Road Network & Potential Development \\
\hline $\mathbf{1 9 4 4 - 1 9 7 2}$ & $-446.213,86$ & $417.549,79$ & $44.724,48$ \\
$\mathbf{1 9 7 2 - 1 9 8 9}$ & $-373.975,63$ & $257.449,16$ & $101.225,62$ \\
$\mathbf{1 9 8 9 - 2 0 0 4}$ & $-481.281,95$ & $429.383,11$ & $51.024,48$ \\
$\mathbf{2 0 0 4 - 2 0 1 4}$ & $-637.385,63$ & $691.312,58$ & $-54.145,00$ \\
\hline
\end{tabular}

If we study the transformations in each period with more detail (Table 4), we can make several comments in each case (Fig. 2). On the one hand, we can see how, as long as time has passed, the slope of the plot of land transformation has changed. More precisely the slope of the processing facilities has been declining due to two reasons. On the one hand, the large increase in land consumption of road due to the work of the northern bypass. On the other hand because, especially in the last interval (2004-2014), the reduction in the rate of occu pancy and construction due to the economic crisis. In turn, the resulting graph of the agricultural land occupation rate has a constant slope, although we have to clarify an important aspect. The intervals studied $(1944-72 ; 1972-89 ; 1989-04 ; 2004-14)$ are not equal. In fact, they occupy 28, 17, 15 and 10 years, respectively. Therefore, even though the transforming surface included has always been around 130 ha., the intensity was much greater in the periods 1989-04 and 2004-14.

Meanwhile, one of the consequences that has taken place in the last 70 years is the contact lost with La Huerta with "Transitos" road. "Transitos" has been during much more of the twentieth century the main route of the city connecting north and south by a ring road. As shown in the figures, in 1944 contact with la Huerta was fully happening, but in the following years, the growth of the districts of Orriols-Torrefiel and neighbouring Benicalap and Benimaclet have finished dismay and seal the entire land of la Huerta.

Furthermore, it is significant the emergence since 1989 of a large concentration of city facilities just in this area. We refer to the Renfe Railway Station, Levante Stadium, the consolidation of the Valencian Library, the Polytechnic University of Valencia (UPV), the Conference Palace of Valencia, ... The services are difficult to accommodate their size inside the city, however, they found a possible place in the Northern Arch, connected to the new round of the city. 


\section{CONCLUSIONS}

Assessing the past 70 years of evolution of the transformations of North Arch of Valencia, Fig. 3, we can affirm that the major transformations developed on the area have occurred during the last 10 years. This has happened regarding magnitude as well as speed and aggressiveness, the most intense of it. If the rate of transformation done during the last decade
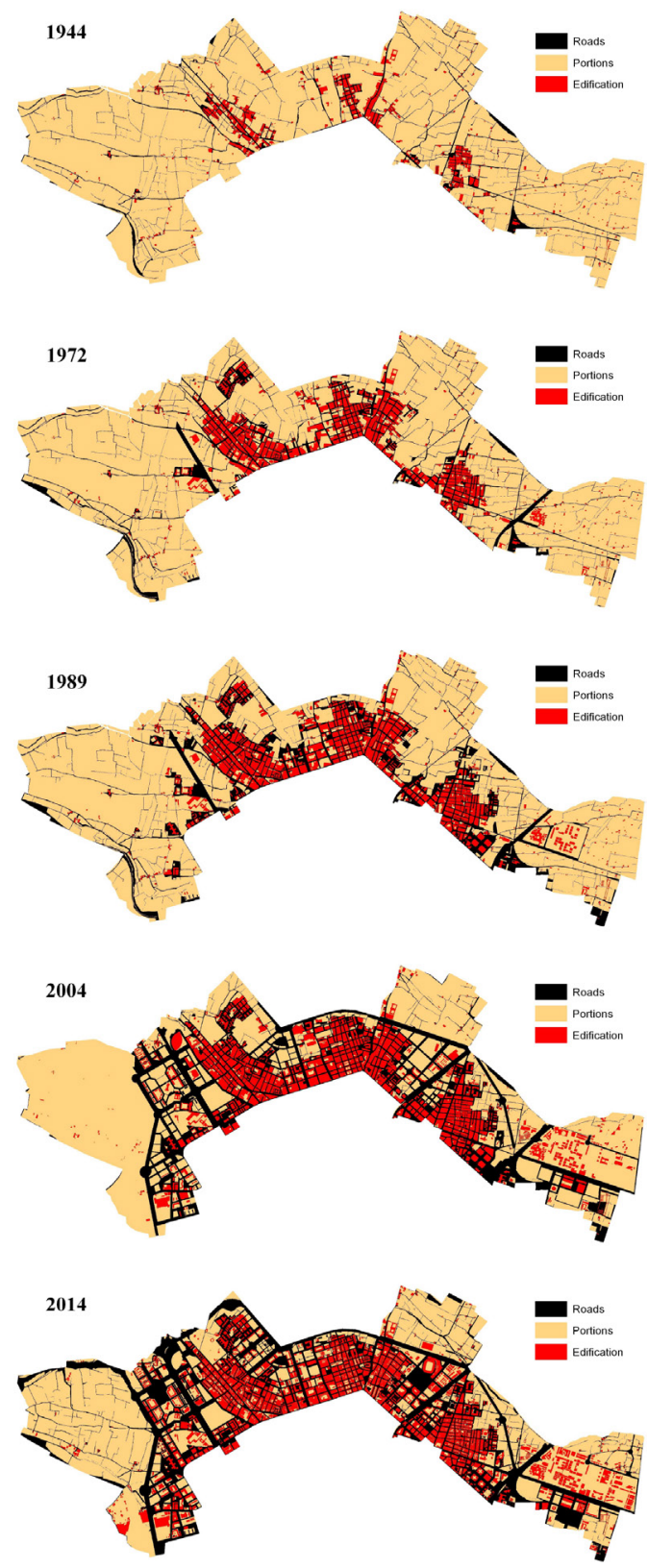

Figure 3: Map evolution of North arch of La Huerta of Valencia. 
is maintained, in less than 40 years this territory will disappear and the historical Huerta with it [2].

In the last 70 years in the North Arch of Valencia, there has been a loss of garden area close to 510 hectares. The basic structure of la Huerta has tried to survive, although it is clear that disconnections and ruptures with the new geometries of road infrastructure have left meaningless many of the original paths. Have been done some interesting efforts to set some alternatives to deal these farmland, but have not finished developing [7]. Until just over one year, the UPV supported the reclassification of land in undeveloped Huerta (72 ha.) established in the Urban General Plan review. In this Plan, 22 ha. correspond to the expansion of the University, while 14 ha. were requalification for a new round road that was supposed to pass next to the Hermitage of Vera and exhausting northern Valencia's free land area. Fortunately, partly thanks to the collective claim as "Per l'Horta" and a group of professors from the University [8], it was possible to stop the initiative, at least until now.

One of the promises to give a full meaning to the protection and management of La Huerta, is deposited on the application and implementation of the Plan of Territorial Action of the Huerta de Valencia. Although almost five years after the processing of the document and with a political change at the municipality and regional government, those promises might remain forgotten and La Huerta again condemned to gradual disappearance or its inevitable decline.

\section{REFERENCES}

[1] Guinot, E., El paisaje de la Huerta de Valencia. Elementos de interpretación de su morfología espacial de origen medieval. Historia de la ciudad. V. Tradición y progreso, Colegio Oficial de Arquitectos de la Comunidad Valenciana; Universidad de Valencia; Universidad Politécnica de Valencia; Valencia Ayuntamiento, Valencia, pp. 116-129, 2008.

[2] Temes, R. \& Moya, A., Dynamics of change in the peri-urban landscape of Huerta de Valencia: the case of La Punta (Valencia). WIT Transactions on Ecology and the Environment, 192, pp. 123-131, 2015. http://dx.doi.org/10.2495/ECO150121

[3] Temes, R., El Tapiz de Penélope. Transformaciones residenciales sobre tejidos sin valor patrimonial. PhD. Thesis, Departamento de Urbanismo. ETS de Arquitectura. UPV, Valencia, p. 778, 2007.

[4] Guinot, E., El repartiment feudal de l'Horta de València al segle XIII: jerarquització social i reordenació del paisatge rural. In Els Repartiments medievals a la Corona d'Aragó, eds. E. Guinot \& J. Torró, Publicacions de la Universitat de València:Valencia, 2007.

[5] Sede Electrónica del Catastro de España, available at www.sedecatastro.gob.es

[6] Temes, R. \& Moya, A., Aplicaciones Informáticas al Proyecto Urbano, Servicio de Publiaciones UPV: Valencia, pp. 52-77, 2008.

[7] Miralles, J.L., Environmental management of peri-urban natural resources: L'Horta de Valencia case study. WIT Transactions on Ecology and the Environment, 192, pp. 99-110, 2015. http://dx.doi.org/10.2495/ECO150101

[8] El Levante, available at http://www.levante-emv.com/valencia/2015/01/28/profesoresmovilizan-expansion-upv-costa/1217962.html 